\title{
Quantification of the Reduced Environmental Impacts with Use of Co-Processing in Cement Kilns in India
}

\author{
Ankur Tiwary ${ }^{1}$, Garima Sharma ${ }^{2}$, P.K.Gupta ${ }^{3}$ \\ ${ }^{1,2,3}$ (Central Pollution Control Board, India)
}

\begin{abstract}
Problem statement: Coupled with resource conservation and reduced carbon emissions, coprocessing technology is a preferable alternative for sound and environmental friendly waste disposal over incinerators \& non-scientific methods. It is not only solution to the waste disposal menace, but also reduces burden on secured landfills \& TSDFs. Methodology: Apart from using energy and material value of wastes, coprocessing not only fixes the inorganic content of the wastes within the clinker, but also, it destroys the wastes completely due to high temperature and long residence time, avoiding need of further processing as in case of incineration. Trial run identifies wastes suitable for co-processing, source emission monitoring assesses environmental impacts and the quantification of reduced environmental impacts gives a clear picture of actual benefits of co-processing. Findings: The results show that the suggested process is efficient, economized and environmental friendly, particularly for a populated country, such as India, as there was no adverse effect on quality of cement, stack emission and air quality of environment due to co-processing of variety of identified wastes in cement kiln. Also, the quantified data of coal saved, $\mathrm{CO}_{2}$ emissions reduced \& landfill volume avoided by the waste utilization will help in convincing all the stakeholders that co-processing of waste is the best environmentally sound technology for waste disposal.
\end{abstract}

Keywords: Conservation of fossil fuel, Energy Recovery, Impact on environment, Material Recycling, SLFs, etc.

\section{Introduction}

Every year, about 6.2 million tonnes of hazardous wastes $(\mathrm{HW})$ are generated in India, out of which around 3.09 million tonnes are recyclable, 0.41 million tonnes are incinerable and 2.73 million tonnes are landfillable. The categorization of hazardous wastes into three classes namely recyclable, incinerable and landfillable, is based on the hazard potential and their characteristics, guiding their ultimate disposal in accordance with the Hazardous Wastes (Management and Handling \& Transboundary Movement) Rules, 2008 [1]. 40,722 hazardous waste generating units exist in India. Most of these wastes have characteristics suited to their utilization as resource material either for recovery of energy or materials or both. Hence, a new mind-set treating hazardous waste as a resource material rather than a difficult disposable material is the need of the hour [2].

The Basel Convention places obligations on party countries to ensure environmentally sound management (ESM) of hazardous and other wastes. In this regard, the guiding principle for securing a more sustainable waste management system is the waste hierarchy of management practices, including giving due consideration to the protection of the environment and human health. This places waste prevention or avoidance in a preeminent position. Where waste avoidance is not possible, reuse, recycling and recovery of waste are preferable alternatives to non-recovery operations. As an example, co-processing in cement kilns provides an environmentally sound resource recovery option preferable to land-filling and incineration [2]. The problems of limited capacity of incinerators \& secure land-fills (SLFs), high costs of disposal along with restrictions in interstate movement of wastes, can be effectively addressed by co-processing of these wastes in cement kilns, if existing in the same state. The Basel Convention stipulates that any transboundary export, import, or transit is permitted only when both the movement and the disposal of the hazardous wastes are environmentally sound [3]. The numerous potential benefits of co-processing include recovery of the energy content of waste, conservation of non- renewable fossil fuels and natural resources, reduction of $\mathrm{CO}_{2}$ emissions, reduction in production costs, and use of an existing technology to treat hazardous wastes [4][5][6][7]. Cost savings that are derived from the use of pre-existing kiln infrastructure to co-process waste that cannot be minimized or otherwise recycled avoid the need to invest in purpose-built incinerators or landfill facilities [8][9]. When compared to conventional incineration, there is a triple benefit in co-processing in terms of energy recovery, saving of fuel and resource conservation, besides reduction in carbon dioxide emissions. The acidic gases, if any, generated during co-processing get neutralized, since the raw material is alkaline in nature. Such phenomenon also reduces resource requirement such as coal and lime stone. Thus, utilization of hazardous/nonhazardous (NHW) wastes by co-processing in cement kilns makes a win-win situation [2]. 
Co-processing is the use of waste as raw material, or as a source of energy, or both to replace natural mineral resources (material recycling) and fossil fuels such as coal, petroleum and gas (energy recovery) in industrial processes, mainly in energy intensive industries (EII) such as cement industry etc. Waste materials used for co-processing are referred to as alternative fuels and raw materials (AFR) [10]. Co-processing is a sustainable development concept based on the principles of industrial ecology focussing on the potential role of industry in reducing environmental burdens throughout the product life cycle [11][12]. One of the most important goals of industrial ecology is to make one industry's waste another's raw material [13]. Co-processing reduces demands on natural resources, reduces pollution and landfill space, thus contributing to reducing the environmental footprint. Co-processing is used for either energy recovery i.e. by substitution of fossil energy by the energy content of the waste (i.e. $\mathrm{C}$ and $\mathrm{H}$ ); or material recovery i.e. by substitution of raw material by material content of the waste (i.e. $\mathrm{CaO}, \mathrm{Al} 2 \mathrm{O} 3, \mathrm{SiO} 2, \mathrm{Fe} 2 \mathrm{O} 3, \mathrm{SO} 3$ ); or both i.e. by substitution of fossil energy and raw material by waste collectively. The selection of types of co-processing is based on the calorific value (CV) of fuel and the selection criterion is as per the accept/refuse chart (Fig. 1.) of the guidelines on coprocessing in cement/power/steel industry [2].

(Source: $\mathrm{CPCB})$

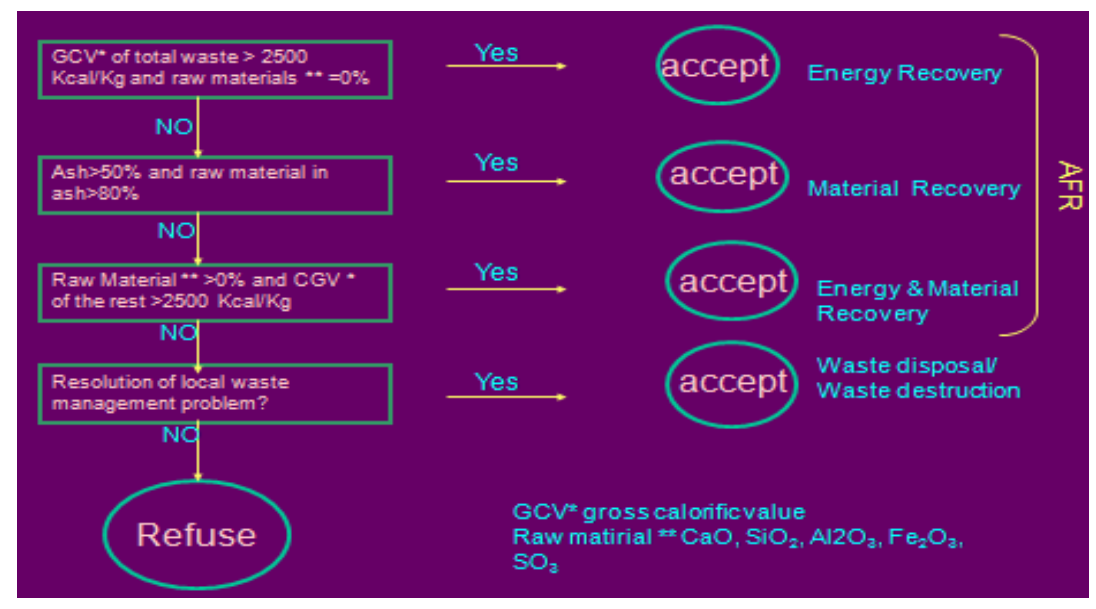

Fig. 1: accept/refuse flowchart for a cement plant operator

The co-processing of waste using cement kilns has been widely and successfully used in the United States, Europe, Japan, and other developed countries for several decades [14]. In many developing countries, there are few high temperature incinerators only for waste disposal; currently, high temperature cement kilns are common and seem to offer an affordable and sustainable treatment alternative. In addition to China, some developing countries that are starting to co-process wastes using cement kilns include Malaysia, Pakistan, Tanzania, Vietnam, and Sri Lanka [14]. Concept of co-processing was introduced in India, for the first time, in January 2005. India has a large number of cement plants and being a developing country, there is a huge potential of waste generation which can be disposed in cement kilns. High temperature (up to $1400^{\circ} \mathrm{C}$ ) and residence time (> 4-5 seconds) with oxygen rich atmosphere of the cement kilns ensure complete destruction of organic compounds found in any waste, giving better destruction efficiency than incinerator. The high temperature alkaline media in cement kiln can effectively absorb variety of chemicals/elements released from waste, without affecting the quality of cement. Further, interaction of the flue gases and the raw material present in kiln ensures that the non-combustible part of the residue is held back in the process and is incorporated into the clinker matrix practically, in an irreversible manner. Also, no waste is generated that requires subsequent processing. Co-processing is helpful in reduction of emissions as land-filling or incineration of waste and utilization of coal in cement kilns result in separate emissions to environment, but if the waste is utilized by replacing fixed amount of coal in cement kiln only, it not only reduces the emissions caused by the replaced amount of coal but also saves the natural resource at the same time.

Huang et al [15] conducted a study to identify environmental risks due to co-processing of wastes. The findings revealed that when wastes containing heavy metals are co-processed in cement kilns, almost all nonvolatile and semi-volatile heavy metals are transferred into the cement minerals during cement clinker formation and these heavy metals in clinker and cement products release gradually when they are exposed to rainfall and as carbonation, but the drawback was that it did not include the risk factors of various other pollutants besides heavy metals. Under obsolete pesticide management project, study of Li et al [16] revealed that wastes being most difficultly decomposed in nature, can be highly decomposed with high feeding rate (up to $2000 \mathrm{~kg} / \mathrm{h}$ ) in New Suspension Pre-calciner (NSP) cement kiln without any negative environmental impact, but it remained confined only to a single type of waste i.e. DDT (dichlorodiphenyltrichloroethane, a Persistent Organic 
Pollutant, POP). Garcia et al [17] conducted a study to describe the effects of a mixture of wastes co-processed in an industrial rotary kiln on cement properties. The findings revealed that waste co-processing provides energy gains without changing the gas emissions and the quality of the produced clinker, but the drawback was that it did not involve quantification of benefits of co-processing \& other risk factors. Bundela et al [18] in their study made the observation that co-processing technology can provide a better, economically and ecologically more sustainable solution to industrial waste management problem, but the drawback was that it focused only on the trial burn of spent carbon waste. Shukla et al [2] came up with the accept/refuse chart based on CVs of wastes for the cement plant operator according to which, the wastes having CVs even a little lesser than $2500 \mathrm{Kcal} / \mathrm{Kg}$, will be routed to TSDFs, SLFs or incinerators, which needs to be addressed. Of the present literature, it is evident that presentation of environmental risk factors due to co-processing specific waste, as done by Huang et al [15], is not sufficient enough to figure out the overall impact assessment on environment due to variety of hazardous and non-hazardous wastes co-processing. The present study emphasizes on quantification of reduced environmental impacts by use of co-processing along with identification of variety of hazardous and nonhazardous wastes and assessing the risk factors due to emission of all possible pollutants through waste coprocessing.

The objectives of the study were: (1) to identify the wastes suitable for utilizing in co-processing in Indian cement kilns; (2) to see the impacts of co-processing the identified wastes on environment and (3) to quantify the reduced environmental impacts in terms of reduction in greenhouse gas emissions; amount of coal and landfill volume saved due to utilization of the identified wastes.

\section{Material And Methods}

In order to facilitate environmentally sound management of wastes and to develop a standard methodology taking all essential safeguards in India, Shukla et al [2] developed "guidelines on co-processing in Cement Industry". The Accept - Refuse Chart, of annexure-4 of the guidelines (Fig. 1.), is used in considering which type of substance is suitable for co-processing. As a basic rule, waste accepted must give an added value for the cement kiln: calorific value from the organic part \& material value from the mineral part. Hazardous Wastes (Management, Handling and Transboundary Movement) Rules, 2008 [1], regulate the management and handling of different types of hazardous wastes, which require the State Pollution Control Boards (SPCBs)/Pollution Control Committees (PCCs) to grant authorization to the operator of a facility based on technical capability, which then send their wastes to cement plants for co-processing. Permission for trial run of hazardous \& non-hazardous wastes is granted by concerned SPCBs/PCCs.

\subsection{Identification of suitable wastes for co-processing}

A wide range of hazardous wastes are suitable for co-processing, but selection of wastes is influenced by various factors, including nature of the waste; its hazardous characteristics; available waste management operations; kiln operation; raw material and fuel compositions; waste feed points; exhaust gas cleaning process; resulting clinker quality; general environmental impacts; probability of formation and release of POPs; particular waste management considerations; regulatory compliance; and public and government acceptance [19][7][20][21]. To identify a waste suitable for co-processing in cement kiln, trial run of a waste is mandatory, to know its emission impacts on the environment. Thus, trial runs were carried out in three phases namely emission monitoring during pre co-processing i.e. kiln operation with fuel, but without using waste (for one day); during co-processing i.e. kiln operation using fuel \& waste, at a fixed percentage of waste (for three days); and during post co-processing i.e. kiln operation with fuel but without using waste (for one day). Based on the recommended frequency of monitoring, a 24 hourly daily sampling plan was drawn to sample the flue gas emissions for various pollutants, for detailed emission monitoring before, after and during trial run of coprocessing of hazardous wastes in cement kiln as per the guidelines and the following pollutants were analyzed: $\mathrm{PM}$ (2 samples), $\mathrm{SO}_{2}$ (4 samples), $\mathrm{NO}_{\mathrm{X}}$ (4 samples), $\mathrm{CO}$ (4 samples), TOC (3 samples), HF (4 samples), HC (2 samples), VOC (2 samples), PAH (2 samples), Heavy Metals (1 sample), CN (1 sample) and Dioxins \& Furans (1 sample). Thus, only those wastes were considered suitable for co-processing, which passed the acceptance criteria and when used with the fuel in cement kilns, caused lesser emissions than the emissions caused by using fuel alone i.e. baseline emissions [2]. For source emissions, sampling and analytical methods are the important criteria as the accuracy of test results are dependent on the test methods adopted for sampling and analysis besides the experience of the personnel. The test methods adopted during sampling and analysis are detailed in Table-1. 
Table-1: Sampling and analytical methods for source emissions

\begin{tabular}{|c|c|c|c|c|}
\hline $\begin{array}{l}\text { Sr. } \\
\text { No. }\end{array}$ & Parameters & $\begin{array}{l}\text { Sampling } \\
\text { Method }\end{array}$ & Methodology & $\begin{array}{l}\text { Equipment and } \\
\text { Chemicals }\end{array}$ \\
\hline 1 & $\begin{array}{l}\text { Sulphur } \\
\text { dioxide }\left(\mathrm{SO}_{2}\right)\end{array}$ & $\begin{array}{l}\text { USEPA } \\
\text { Method } 6\end{array}$ & $\begin{array}{l}\text { Flue gas is passed through hydrogen } \\
\text { peroxide, oxidized sulphate is estimated } \\
\text { using the Barium perchlorate }\end{array}$ & $\begin{array}{l}\text { Calibrated stack gas } \\
\text { monitoring kit, } \mathrm{H}_{2} \mathrm{O}_{2} \text {, } \\
\text { Thorin indicator, } \\
\text { Barium perchlorate }\end{array}$ \\
\hline 2 & $\begin{array}{l}\text { Hydrochloric } \\
\text { Acid }(\mathrm{HCl}) \& \\
\text { Hydrogen } \\
\text { Fluoride }(\mathrm{HF})\end{array}$ & $\begin{array}{c}\text { USEPA } \\
\text { Method 26A }\end{array}$ & $\begin{array}{l}\text { Gaseous and particulate pollutants are } \\
\text { withdrawn from an emission source and } \\
\text { are collected on a filter and in absorbing } \\
\text { solution }\end{array}$ & $\begin{array}{l}\mathrm{H}_{2} \mathrm{SO}_{4}, \mathrm{NaOH}, \\
\text { Thimbles GF, Acetone, } \\
\text { Sodium Thiosulphate. }\end{array}$ \\
\hline 3 & $\begin{array}{l}\text { Carbon } \\
\text { monoxide } \\
(\mathrm{CO})\end{array}$ & $\begin{array}{l}\text { USEPA } \\
\text { Method } 60 \\
\text { App. A- } \\
0010 \mathrm{~B}\end{array}$ & NDIR method /GC Method & GC / NDIR \\
\hline 4 & $\begin{array}{l}\text { Oxides of } \\
\text { Nitrogen } \\
\left(\mathrm{NO}_{\mathrm{X}}\right)\end{array}$ & $\begin{array}{c}\text { USEPA } \\
\text { Method } 7\end{array}$ & $\begin{array}{l}\text { Flue gas is absorbed into acidified } \\
\text { Hydrogen peroxide, Nitrates are estimated } \\
\text { by phenoldisulphonic acid } \\
\text { spectrophotometrically }\end{array}$ & $\begin{array}{l}\text { Calibrated stack gas } \\
\text { monitoring kit, Liter } \\
\text { flask with three way } \\
\text { stopper cock, Sulphuric } \\
\text { acid, Phenoldisulphonic } \\
\text { acid, spectrophotometer }\end{array}$ \\
\hline 5 & $\begin{array}{l}\text { Total Organic } \\
\text { Carbon (TOC) }\end{array}$ & $\begin{array}{l}\text { USEPA } \\
\text { Method } 30 \\
\& \text { Method } \\
10\end{array}$ & $\begin{array}{l}\text { Gas sampling is performed Iso-Kinetically } \\
\text { and the Vapour organic compounds are } \\
\text { absorbed into XAD-2. The pooled } \\
\text { components of the sampling train (Such } \\
\text { as Thimble, Line washings and XAD2) } \\
\text { are extracted by dichloromethane and split } \\
\text { to analyze the organic compounds by } \\
\text { GC/FID and gravimetrically }\end{array}$ & $\begin{array}{l}\text { Stack Monitoring Kit, } \\
\text { XAD-2, Dichloro- } \\
\text { Methane, GC/FID }\end{array}$ \\
\hline 6 & $\begin{array}{l}\text { Hydrogen } \\
\text { Fluoride (HF) }\end{array}$ & $\begin{array}{c}\text { USEPA } \\
\text { Method 13A }\end{array}$ & $\begin{array}{l}\text { Gaseous and Particulate fluorides are } \\
\text { withdrawn Iso-Kinetically from the source } \\
\text { and collected in water and on a filter. The } \\
\text { total fluoride is then determined by Ion } \\
\text { Selective electrode }\end{array}$ & $\begin{array}{l}\text { Stack Monitoring Kit, } \\
\text { Thimbles GF, CaO, } \\
\mathrm{NaOH}, \mathrm{H}_{2} \mathrm{SO}_{4}, \mathrm{HCl} \text {, Ion } \\
\text { Selective Electrode }\end{array}$ \\
\hline 7 & $\begin{array}{l}\text { Particulate } \\
\text { Matter }\end{array}$ & $\begin{array}{l}\text { USEPA } \\
\text { Method } 5\end{array}$ & $\begin{array}{l}\text { Iso-kinetic gas sampling followed by } \\
\text { gravimetric method of measurement }\end{array}$ & $\begin{array}{l}\text { Calibrated stack gas } \\
\text { monitoring kit, } \\
\text { Cellulose thimbles } \\
\end{array}$ \\
\hline 8 & $\begin{array}{l}\text { Total } \\
\text { Hydrocarbons }\end{array}$ & $\begin{array}{c}\text { USEPA } \\
\text { Method 25A }\end{array}$ & By Gas Chromatographic technique & $\mathrm{GC}$ \\
\hline 9 & $\begin{array}{l}\text { Volatile } \\
\text { Organic } \\
\text { Carbons } \\
\text { (VOCs) }\end{array}$ & $\begin{array}{c}\text { USEPA } \\
\text { Method } 30 \\
\text { \& Method } \\
31\end{array}$ & $\begin{array}{l}\text { This method employs a sampling module } \\
\text { and meter box to withdraw a 20-litre } \\
\text { sample of effluent gas containing volatile } \\
\text { Organic compounds from a stationary } \\
\text { source at a flow rate of } 1 \text { liter/minute. The } \\
\text { gas stream is cooled by passage through a } \\
\text { water-cooled condenser and volatile } \\
\text { organic compounds are collected on a set } \\
\text { of sorbent traps. Liquid condensate is } \\
\text { collected in an impinger placed between } \\
\text { the sorbent traps. }\end{array}$ & $\begin{array}{l}\text { Tenax-GC, Anasorb- } \\
\text { GC \& Petroleum- } \\
\text { Charcoal \& GC/ FID }\end{array}$ \\
\hline 10 & $\begin{array}{l}\text { Poly Aromatic } \\
\text { Hydrocarbons } \\
\text { (PAH) }\end{array}$ & $\begin{array}{c}\text { USEPA } \\
\text { Method } 23\end{array}$ & $\begin{array}{l}\text { A sample is drawn iso-Kinetically from } \\
\text { the gas stream and the PAH is adsorbed } \\
\text { on to the packed column of XAD-2, The } \\
\text { PAH is analyzed by means of GC. }\end{array}$ & $\begin{array}{l}\text { Thimbles, XAD-2, } \\
\mathrm{Na}_{2} \mathrm{SO}_{4}, \mathrm{KOH}, \\
\mathrm{H}_{2} \mathrm{SO}_{4}, \mathrm{Hexane}, \\
\text { Methylene Chloride, } \\
\text { Benzene, Methanol }\end{array}$ \\
\hline 11 & $\begin{array}{l}\text { Metals in } \\
\text { Particulates } \\
\text { (Total } \\
\text { particulates } \\
\text { and metals) }\end{array}$ & $\begin{array}{c}\text { USEPA } \\
\text { Method } 29\end{array}$ & $\begin{array}{l}\text { A sample is drawn Iso-Kinetically on to a } \\
\text { glass fibre thimble. The thimble is } \\
\text { extracted by means of } \mathrm{HCl} / \mathrm{HNO}_{3} \text { and } \\
\text { analyzed by ICP/AAS }\end{array}$ & $\begin{array}{l}\text { Thimbles } \mathrm{GF}, \mathrm{HNO}_{3} \\
\mathrm{H}_{2} \mathrm{SO}_{4}, \mathrm{H}_{2} \mathrm{O}_{2} \& \mathrm{HCl}\end{array}$ \\
\hline 12 & $\begin{array}{l}\text { Metals in } \\
\text { Vapour }\end{array}$ & $\begin{array}{c}\text { USEPA } \\
\text { Method } 29\end{array}$ & $\begin{array}{l}\text { The sample is absorbed into the acidified } \\
\text { hydrogen peroxide solution, the resultant } \\
\text { is digested and analyzed by means of } \\
\text { ICP/AAS }\end{array}$ & $\begin{array}{l}\mathrm{HNO}_{3}, \mathrm{H}_{2} \mathrm{SO}_{4}, \mathrm{H}_{2} \mathrm{O}_{2} \& \\
\mathrm{HCl}\end{array}$ \\
\hline 13 & $\begin{array}{l}\text { Dioxins \& } \\
\text { Furans }\end{array}$ & $\begin{array}{c}\text { USEPA } \\
\text { Method } 23 \\
\text { A }\end{array}$ & $\begin{array}{l}\text { A sample is drawn iso-kinetically on to a } \\
\text { glass fibre filter paper and dragger tube. } \\
\text { The sample is extracted for } 18 \text { hours and } \\
\text { analyzed by HRGC / HRMS }\end{array}$ & $\begin{array}{l}\text { Filter paper, XAD-2, } \\
\text { Acetone, Toluene, } \\
\text { DCM }\end{array}$ \\
\hline 14 & Cyanide & CTM 27 & $\begin{array}{l}\text { A sample is drawn iso-kinetically in } \\
\text { sodium hydroxide medium and analysed } \\
\text { by ion analyzer }\end{array}$ & $\mathrm{NaOH}$ \\
\hline
\end{tabular}

(Source: $\mathrm{CPCB}$ ) 


\subsection{Environmental Impacts of Waste Co-processing}

After successful trial run, a proper procedure is followed for obtaining the regular permission for coprocessing of identified non-hazardous wastes, which is granted by respective SPCBs/PCCs \& for hazardous wastes, regular permission is granted by us at CPCB under the rule 11 of HW MHTM Rules [1] and obtaining such approval before-hand is mandatory.

In order to see the impacts of waste co-processing, regular monitoring in existing plants, where permission had already been granted for regular co-processing of waste in cement kiln by SPCBs/CPCB, was conducted through M/s Vimta Labs Ltd., Hyderabad (a CPCB certified agency) at two cement plants namely M/s Ultratech Cement Ltd., Reddipalayam Cement Works, Tamilnadu, (using paint sludge, tyre chips, ETP sludge, de-oiled rice bran and oily cotton wastes); and M/s Lafarge India Pvt. Ltd., Sonadih Cement Plant, Chhattisgarh (using TDI tar sludge and waste mix solid \& waste mix liquid), during 2011- 2012. Here also, 24 hourly daily sampling plans were followed to sample the flue gas emissions. During this one year regular study, baseline emission data was generated during normal operation of cement plant (i.e. with conventional fuel only) by source emission monitoring; conventional fuel analysis; ambient air quality (AAQ) monitoring for 3 days and clinker \& raw meal analysis (taking one representative sample). Further, data during regular co-processing (i.e. with fuel+waste) in cement kiln was generated for one year, including waste analysis (quarterly sample for one year); emission monitoring (twice in a month for one year); AAQ monitoring (twice in a week for one year); clinker analysis \& raw meal analysis (quarterly sample for one year). The emission monitoring was carried out for $\mathrm{PM}, \mathrm{CO}, \mathrm{TOC}, \mathrm{NOx}, \mathrm{HCl}, \mathrm{SO} 2, \mathrm{HF}$, total dioxins and furans, $\mathrm{Cd}+\mathrm{Tl}+$ their compounds, $\mathrm{Hg}$ and its compounds, $\mathrm{Sb}+\mathrm{As}+\mathrm{Pb}+\mathrm{Co}+\mathrm{Cr}+\mathrm{Cu}+\mathrm{Mn}+\mathrm{Ni}+\mathrm{V}+$ their compounds on fortnightly basis for one year. AAQ was monitored for PM10, PM2.5, SO2, NOx, CO, O3, NH3, C6H6, Benzo(a)Pyrene, Pb, Ni \& As. The leachability tests were conducted for heavy metals in the clinker samples, which were obtained prior to coprocessing and during co-processing. The tests for compressive strength of cement were done on monthly basis. Various other parameters like $\mathrm{SiO} 2, \mathrm{Al} 2 \mathrm{O} 3, \mathrm{Fe} 2 \mathrm{O} 3, \mathrm{CaO}, \mathrm{Mg}, \mathrm{SO} 3$ etc. were analysed in clinker samples.

\subsection{Quantification of $\mathrm{CO} 2$ emission reduction, coal and landfill volume saved}

The data regarding quantity of utilization of hazardous \& non-hazardous wastes by cement plants having regular permissions granted by CPCB \& SPCBs/PCCs respectively, were collected during the full study period i.e. for 2010-2011, 2011-2012 \& 2012-2013. After collecting the data of quantity of wastes utilized, the amount of $\mathrm{CO} 2$ emission reduction and coal \& landfill volume saved were calculated taking certain assumptions as: every 1 ton of RDF (i.e. partial biomass) replaces 0.7 ton coal \& reduces 1.36 ton $\mathrm{CO} 2$; 1 ton of tyre (i.e. $50 \%$ biomass) replaces 1 ton coal \& reduces 2.4 ton $\mathrm{CO} 2$; 1 ton of processed sewage (i.e. 100\% biomass) replaces 0.6 ton coal \& reduces 1.4 ton $\mathrm{CO} 2 ; 1$ ton of solvent fuel (i.e. non-biomass) replaces 0.9 ton coal \& reduces 1.7 ton $\mathrm{CO} 2$; 1 ton of recovered oil (i.e. non-biomass) replaces 1.3 ton coal \& reduces 2.5 ton CO2. For SLF volume calculation: for planning purposes, a density of $0.85 \mathrm{t} / \mathrm{cu} . \mathrm{m}$. has been adopted for biodegradable wastes with higher values (typically $1.1 \mathrm{t} / \mathrm{cu} . \mathrm{m}$.) for inert waste [22].

\section{Results}

Our study involved identification of wastes suitable for co-processing based on calorific values, being used for energy recovery or material recovery or both, but without causing any adverse environmental impacts and thus helped in quantification of reduced environmental impacts of co-processing in terms of GHGs emission reduction, coal and SLF volume saved. The study was conducted from April, 2010 to March, 2013 at CPCB, Delhi. A total of 21 cement plants, which were co-processing the identified suitable wastes on regular basis, were included in the study. We visited all the cement plants to do the source emission monitoring during trial run of waste co-processing and regular co-processing as per the procedure mentioned in Table-1. The analysis of data resulted in following observations:

\subsection{Identification of Suitable Wastes}

During the study period i.e. 2010-2013, various wastes were analyzed based on their characteristics/chemical attributes. Trial runs were conducted for co-processing of these analyzed wastes. Based on successful trial runs in 17 Indian cement plants, namely M/s ACC Ltd. (7 units); M/s Ultratech Cement Ltd., (4 units); M/s Ambuja Cement Ltd., (3 units); M/s Shree Cement Ltd. (1 unit); M/s Lafarge India Pvt. Ltd. (1 unit) \& M/s My Home Industries Ltd. (1 unit)., 36 different hazardous wastes (like ETP sludge; paint sludge; waste mix liquid \& waste mix solid; waste/residue containing oil; phosphate sludge; spent wash concentrate; spent catalyst; organic plating sludge \& dyeing sludge; benzofuran; spent clay; spent carbon; grinding waste; oil soaked cloth; acid tar sludge; liquid organic spent solvent; contaminated plastic waste \& incineration ash etc.) were identified suitable for co-processing. The wastes identified had calorific values in the range of $80 \mathrm{Kcal} / \mathrm{Kg}$ to $8688 \mathrm{Kcal} / \mathrm{Kg}$, which were allowed for co-processing at fixed percentage utilization, varying from $0.05 \%$ to $12.03 \%$. The commonly used combustible wastes in the cement industries are summarized in Table-2. Calorific 
value is the key parameter for the energy provided to the process. The overall moisture content may affect productivity, efficiency and also increase energy consumption. The water content of waste needs to be considered in conjunction with that of conventional fuels and/or raw feed materials. The ash content affects the chemical composition of the cement and may require an adjustment of the composition of the raw mix. It was observed that the wastes with higher CVs and lower moisture contents were considered most suitable for coprocessing, as they did not require pre-processing and could directly be fed to cement kilns like tire chips and tire derived fuel.

Table-2: Some commonly used wastes identified suitable for co-processing in Indian cement industry

\begin{tabular}{|l|l|l|c|c|c|c|c|}
\hline S. N. & \multicolumn{1}{|c|}{ Fuel type } & Source & $\begin{array}{c}\text { Calorific value } \\
\text { (Kcal/kg) }\end{array}$ & $\begin{array}{c}\text { Carbon } \\
\text { content }\end{array}$ & $\begin{array}{c}\text { Ash } \\
\text { content }\end{array}$ & $\begin{array}{c}\text { Moisture } \\
\text { content }\end{array}$ & $\begin{array}{c}\text { Hazardous } \\
\text { (Hon- } \\
\text { hazardous } \\
\text { (NH) }\end{array}$ \\
\hline 1. & Benzofuran & Pharmaceutical & 5082 & $49.15 \%$ & - & - & $\mathrm{H}$ \\
\hline 2. & Paint sludge & $\begin{array}{c}\text { Automobile } \\
\text { industry }\end{array}$ & 4490 & $62.46 \%$ & $17.94 \%$ & $5.20 \%$ & $\mathrm{H}$ \\
\hline 3. & ETP sludge & Textile industry & 3367 & $7.1 \%$ & $31.3 \%$ & $12.8 \%$ & $\mathrm{H}$ \\
\hline 4. & Organic Solvent & Pharmaceutical & 2900 & $25 \%$ & - & - & $\mathrm{H}$ \\
\hline 5. & Petcoke & Oil refinery & 7844 & $79 \%$ & $1.8 \%$ & $1.8 \%$ & $\mathrm{NH}$ \\
\hline 6. & Tyre chips & $\begin{array}{c}\text { Tire } \\
\text { manufacturing } \\
\text { industry }\end{array}$ & 6632 & $87 \%$ & $2.20 \%$ & $0.10 \%$ & $\mathrm{NH}$ \\
\hline 7. & $\begin{array}{l}\text { Refuse Derived } \\
\text { Fuel }\end{array}$ & $\begin{array}{c}\text { Municipal solid } \\
\text { waste and agro } \\
\text { waste. }\end{array}$ & 2789 & $42 \%$ & $21.9 \%$ & $7.2 \%$ & $\mathrm{NH}$ \\
\hline 8. & $\begin{array}{l}\text { Ground nut } \\
\text { shell }\end{array}$ & $\begin{array}{c}\text { Agricultural } \\
\text { waste }\end{array}$ & 4200 & $15.50 \%$ & $20.3 \%$ & $8.76 \%$ & $\mathrm{NH}$ \\
\hline 9. & Tire derived & $\begin{array}{c}\text { Tire } \\
\text { manufacturing } \\
\text { industry }\end{array}$ & 6450 & $28.13 \%$ & $4.81 \%$ & $0.62 \%$ & $\mathrm{NH}$ \\
\hline 10. & Rice husk & $\begin{array}{c}\text { Rice milling } \\
\text { industry }\end{array}$ & 3410 & $42.2 \%$ & $17-26 \%$ & $11 \%$ & $\mathrm{NH}$ \\
\hline 11. & Saw dust & $\begin{array}{c}\text { Saw mills \& } \\
\text { wood product } \\
\text { industry }\end{array}$ & 4810 & $40 \%$ & $1.3 \%$ & $40-60 \%$ & $\mathrm{NH}$ \\
\hline 12. & Spent wash & Distillery & 2000 & $10.59 \%$ & $10.59 \%$ & $17.01 \%$ & $\mathrm{NH}$ \\
\hline
\end{tabular}

(Data Source:CPCB)

3.2 Monitoring at M/s Ultratech Cement Ltd., Reddipalayam Cement Works, Tamilnadu, and M/s Lafarge India Pvt. Ltd., Sonadih Cement Plant, Chhattisgarh

The emission monitoring was carried out for PM, CO, TOC, NOx, HCl, SO2, HF, total dioxins and furans, $\mathrm{Cd}+\mathrm{Tl}+$ their compounds, $\mathrm{Hg}$ and its compounds, $\mathrm{Sb}+\mathrm{As}+\mathrm{Pb}+\mathrm{Co}+\mathrm{Cr}+\mathrm{Cu}+\mathrm{Mn}+\mathrm{Ni}+\mathrm{V}+$ their compounds on fortnightly basis for one year during 2011- 2012 at M/s Ultratech Cement Ltd., Reddipalayam Cement Works, Tamilnadu and M/s Lafarge India Pvt. Ltd., Sonadih Cement Plant, Chhattisgarh. Summary of the emission monitoring data is presented in Table-3. Column (2) and column (4) of the Table-3 represent the baseline emission data (i.e. emissions by using coal only) generated for three days each at $\mathrm{M} / \mathrm{s}$ Ultratech Cement Ltd. and M/s Lafarge India Pvt. Ltd. respectively, during pre co-processing period, quantified as the range of minimum to maximum values. Column (3) and column (5) represent their corresponding emission data by using coal along with waste i.e. during co-processing period. It was observed that PM emissions during co-processing were less than the emission standards prescribed by the SPCBs. For other pollutants i.e. $\mathrm{CO}, \mathrm{TOC}, \mathrm{NOx}, \mathrm{HCl}, \mathrm{SO} 2, \mathrm{HF}$, total dioxins and furans, $\mathrm{Cd}+\mathrm{Tl}+$ their compounds, $\mathrm{Hg}$ and its compounds, $\mathrm{Sb}+\mathrm{As}+\mathrm{Pb}+\mathrm{Co}+\mathrm{Cr}+\mathrm{Cu}+\mathrm{Mn}+\mathrm{Ni}+\mathrm{V}+$ their compounds, the emission values during coprocessing were not exceeding the base line emission data i.e. during pre co-processing period.

Table-3: Source emission monitoring data of co-processing of wastes conducted at two cement plants

\begin{tabular}{|c|c|c|c|c|}
\hline \multirow{4}{*}{$\begin{array}{c}\text { Parameters } \\
\text { Monitored }\end{array}$} & \multicolumn{2}{|c|}{$\begin{array}{c}\text { Emission monitoring conducted at } \\
\text { M/s Ultratech Cement Ltd., } \\
\text { Reddipalayam Cement Works, Tamilnadu } \\
\end{array}$} & \multicolumn{2}{|c|}{$\begin{array}{c}\text { Emission monitoring conducted at } \\
\text { M/s Lafarge India Pvt. Ltd., } \\
\text { Sonadih Cement Plant, Chhattisgarh } \\
\text { (2011-2012) }\end{array}$} \\
\cline { 2 - 5 } & $\begin{array}{c}\text { Baseline Emission } \\
\text { Data i.e. with Coal } \\
\text { Only }\end{array}$ & $\begin{array}{c}\text { Emission Data During } \\
\text { Co-Processing (i.e. Using } \\
\text { Fuel+Waste)* }\end{array}$ & $\begin{array}{c}\text { Baseline Emission } \\
\text { Data i.e. with Coal } \\
\text { Only }\end{array}$ & $\begin{array}{c}\text { Emission Data } \\
\text { During Co- } \\
\text { Processing (i.e. Using }\end{array}$ \\
\hline
\end{tabular}




\begin{tabular}{|c|c|c|c|c|}
\hline & & & & Fuel+Waste)* \\
\hline Column (1) & Column (2) & Column (3) & Column (4) & Column (5) \\
\hline SO2 (mg/Nm3) & $<3.2$ & $<3.2$ & $<3.2$ & $<3.2$ \\
\hline Hydrocarbons (mg/Nm3) & $* * \mathrm{BDL}$ & BDL & BDL & BDL \\
\hline $\mathrm{CO}(\mathrm{mg} / \mathrm{Nm} 3)$ & $90-96$ & $80-98$ & $88-93$ & $68-93$ \\
\hline HF (mg/Nm3) & $1.2-2.5$ & $1.0-2.3$ & $1.8-2.4$ & $1.3-2.4$ \\
\hline $\begin{array}{l}\text { Total Organic Carbon } \\
(\mathrm{mg} / \mathrm{Nm} 3)\end{array}$ & $7.2-7.8$ & $3.1-7.8$ & $6.9-7.5$ & $6.6-7.3$ \\
\hline PAH $(\mu \mathrm{g} / \mathrm{Nm3})$ & $1.67-1.95$ & 0.8 to 1.9 & $1.4-1.9$ & $0.8-1.8$ \\
\hline VOC (mg/Nm3) & $2.5-3.1$ & $1.1-3.1$ & $3.1-4.1$ & $1.4-3.8$ \\
\hline Cyanide $(\mu \mathrm{g} / \mathrm{Nm} 3)$ & $<0.02$ & $<0.02$ & $<0.02$ & $<0.02$ \\
\hline $\begin{array}{l}\text { Total Dioxins and Furans } \\
(\mathrm{ng} / \mathrm{Nm} 3)\end{array}$ & $0.0251-0.0304$ & $0.0186-0.0304$ & $0.0272-0.0304$ & $0.0245-0.0289$ \\
\hline
\end{tabular}

The leachability tests were conducted for heavy metals in the clinker samples which were obtained prior to co-processing and during co-processing at both the plants, which are presented in Table-4. It was observed that the data for leachability tests obtained during co-processing were at par with the samples of pre co-processing period. Hence, there appeared to be no effect on leachability due to co-processing.

Table-4: Leachability tests data for heavy metals in clinker samples

\begin{tabular}{|c|c|c|c|c|}
\hline \multirow{2}{*}{$\begin{array}{l}\text { Parameters } \\
\text { Monitored }\end{array}$} & \multicolumn{2}{|c|}{$\begin{array}{l}\text { Leachability test conducted at } \\
\text { M/s Ultratech Cement Ltd., } \\
\text { Reddipalayam Cement Works, Tamilnadu } \\
\text { (2011-2012) }\end{array}$} & \multicolumn{2}{|c|}{$\begin{array}{l}\text { Leachability test conducted at } \\
\text { M/s Lafarge India Pvt. Ltd., } \\
\text { Sonadih Cement Plant, Chhattisgarh (2011- } \\
\text { 2012) }\end{array}$} \\
\hline & $\begin{array}{c}\text { Baseline Data i.e. } \\
\text { with Coal Only }\end{array}$ & $\begin{array}{l}\text { Data During Co- } \\
\text { Processing (i.e. Using } \\
\text { Fuel+Waste) }\end{array}$ & $\begin{array}{l}\text { Baseline Data i.e. } \\
\text { with Coal Only }\end{array}$ & $\begin{array}{l}\text { Data During Co- } \\
\text { Processing (i.e. Using } \\
\text { Fuel+Waste) }\end{array}$ \\
\hline Lead as $\mathrm{Pb}(\mathrm{mg} / \mathrm{L})$ & 0.10 & $0.03-0.06$ & 0.12 & $0.02-0.09$ \\
\hline Zinc as $\mathrm{Zn}(\mathrm{mg} / \mathrm{L})$ & 0.20 & $0.11-0.17$ & 0.24 & $0.18-0.27$ \\
\hline Tin as $\mathrm{Sn}(\mathrm{mg} / \mathrm{L})$ & 0.01 & $<0.01$ & 0.01 & $<0.01$ \\
\hline Cadmium as $\mathrm{Cd}(\mathrm{mg} / \mathrm{L})$ & $<0.01$ & $<0.01$ & $<0.01$ & $<0.01$ \\
\hline Arsenic as $\mathrm{As}(\mathrm{mg} / \mathrm{L})$ & $<0.01$ & $<0.01$ & $<0.01$ & $<0.01$ \\
\hline Mercury as $\mathrm{Hg}(\mathrm{mg} / \mathrm{L})$ & $<0.001$ & $<0.001$ & $<0.001$ & $<0.001$ \\
\hline Chromium as $\mathrm{Cr}(\mathrm{mg} / \mathrm{L})$ & 0.02 & $0.01-0.03$ & 0.02 & $0.01-0.03$ \\
\hline Cobalt as $\mathrm{Co}(\mathrm{mg} / \mathrm{L})$ & $<0.01$ & $<0.01$ & $<0.01$ & $<0.01$ \\
\hline Nickel as Ni (mg/L) & 0.02 & $0.01-0.02$ & 0.03 & $0.01-0.04$ \\
\hline Thallium as $\mathrm{Tl}(\mathrm{mg} / \mathrm{L})$ & 0.02 & 0.01 & 0.02 & 0.01 \\
\hline Copper as $\mathrm{Cu}(\mathrm{mg} / \mathrm{L})$ & 0.05 & $0.06-0.09$ & 0.09 & $0.11-0.21$ \\
\hline Vanadium as $\mathrm{V}(\mathrm{mg} / \mathrm{L})$ & 0.02 & 0.02 & 0.04 & $0.02-0.06$ \\
\hline Antimony as $\mathrm{Sb}(\mathrm{mg} / \mathrm{L})$ & $<0.01$ & $<0.01$ & $<0.01$ & $<0.01$ \\
\hline Manganese as Mn (mg/L) & 0.06 & $0.06-0.07$ & 0.08 & $0.09-0.22$ \\
\hline Selenium as $\mathrm{Se}(\mathrm{mg} / \mathrm{L})$ & $<0.01$ & $<0.01$ & $<0.01$ & $<0.01$ \\
\hline Cyanide as $\mathrm{CN}(\mathrm{mg} / \mathrm{L})$ & $<0.02$ & $<0.02$ & $<0.02$ & $<0.02$ \\
\hline
\end{tabular}

The data for compressive strength of cement compiled on monthly basis for study period reflected no deviation in the compressive strength of cement due to co-processing. For clinker quality, various other parameters like $\mathrm{SiO} 2, \mathrm{Al} 2 \mathrm{O} 3, \mathrm{Fe} 2 \mathrm{O} 3, \mathrm{CaO}, \mathrm{Mg}$, SO3 etc. were analysed in clinker samples. The monthly average data is presented in Table-5. Very small variation ranges of data during whole one year showed that there was no effect on clinker quality.

Table-5: Parameters tested for clinker quality

\begin{tabular}{|c|c|c|}
\hline \multirow{2}{*}{ Parameters } & $\begin{array}{c}\text { M/s Ultratech Cement Ltd., } \\
\text { Reddipalayam Cement Works, Tamilnadu } \\
(\mathbf{2 0 1 1 - 2 0 1 2 )}\end{array}$ & $\begin{array}{c}\text { M/s Lafarge India Pvt. Ltd., } \\
\text { Sonadih Cement Plant, Chhattisgarh (2011-2012) }\end{array}$ \\
\cline { 2 - 3 } & \multicolumn{2}{|c|}{ Monitored Data Range* } \\
\hline LOI (\%) & $0.19-0.22$ & $0.12-0.30$ \\
\hline $\mathrm{SiO}_{\mathbf{2}}(\%)$ & $21.48-22.18$ & $21.03-21.34$ \\
\hline
\end{tabular}


Quantification of the Reduced Environmental Impacts with Use of Co-Processing in Cement Kilns in India

\begin{tabular}{|c|c|c|}
\hline $\mathbf{A l}_{\mathbf{2}} \mathbf{O}_{\mathbf{3}}(\boldsymbol{\%})$ & $5.27-5.59$ & $4.94-5.48$ \\
\hline $\mathbf{F e}_{\mathbf{2}} \mathbf{O}_{\mathbf{3}}(\boldsymbol{\%})$ & $4.28-4.71$ & $3.07-3.35$ \\
\hline $\mathbf{C a O}(\%)$ & $64.37-65.24$ & $63.29-64.18$ \\
\hline $\mathbf{M g O}(\%)$ & $1.28-1.30$ & $4.12-4.28$ \\
\hline $\mathbf{S O}_{\mathbf{3}}(\boldsymbol{\%})$ & $0.35-1.18$ & $0.28-0.63$ \\
\hline $\mathbf{K}_{\mathbf{2}} \mathbf{O}(\%)$ & $0.21-0.22$ & $0.76-0.96$ \\
\hline $\mathbf{N a}_{\mathbf{2}} \mathbf{O}(\%)$ & $0.66-0.89$ & $0.30-0.36$ \\
\hline LimeSat Factor & $0.90-0.93$ & $92.14-95.99$ \\
\hline Silica Ratio & $2.14-2.31$ & $2.42-2.56$ \\
\hline Alumina Ratio & $1.14-1.31$ & $1.50-1.71$ \\
\hline F CaO (\%) & $1.50-2.01$ & $1.72-2.49$ \\
\hline *Range represents minimum and maximum values of all the twelve values monitored every month during $2011-12$ \\
\hline
\end{tabular}

Also, AAQ was monitored for PM10, PM2.5, SO2, NOx, CO, O3, NH3, C6H6, Benzo(a)Pyrene, Pb, $\mathrm{Ni}$ and As, twice in a week for one year. The summary of data is presented in Table-6, which clearly indicates that AAQ is within the National Ambient Air Quality (NAAQ) standards, prescribed by Ministry of Environment \& Forests (MoEF), India.

Table-6: Ambient air quality (AAQ) data

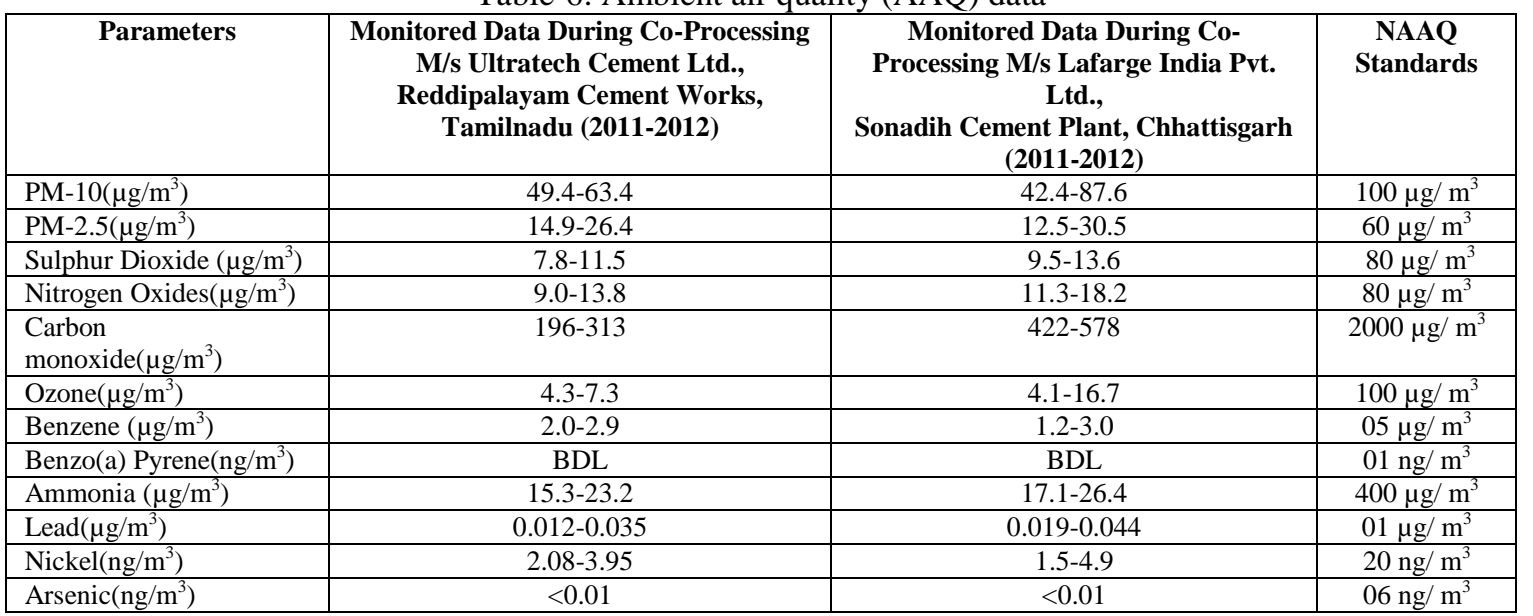

\subsection{Quantification of wastes disposed by co-processing, $\mathrm{CO} 2$ emission reduced and Coal \& Landfill Volume saved}

On analysis of the collected data, it was observed that during 2010-11, 1.89 million tons of wastes were disposed, which replaced 1.68 million tons of coal in cement kilns. Co-processing has helped India in taking a big leap in saving carbon credits. The $\mathrm{CO} 2$ emissions reduced by co-processing of wastes during 2010-11 were 3.20 million tons of $\mathrm{CO} 2 \&$ the avoided volume of SLF were 2.06 million cubic meters. Similarly, during 201112, 0.26 million tons of wastes were disposed, saving 0.19 million tons of coal, $\mathrm{CO} 2$ emissions reduced 0.39 million tons of $\mathrm{CO} 2$ \& the avoided volume of SLF were 0.25 million cubic meters. Further, during 2012-13, 0.27 million tons of wastes were disposed by co-processing \& 0.22 million tons of coal were saved, $\mathrm{CO} 2$ emission reduced were 0.30 million tons of $\mathrm{CO} 2$, whereas the avoided volume of SLF were 0.21 million cubic meters. Thus, during the study period i.e. 2010-2013, 2.42 million tons of wastes disposed through coprocessing have saved 2.1 million tons of coal, thereby, easing out burden on natural fuel resources. This in turn has resulted in reduction of 3.9 million tons of $\mathrm{CO} 2$ emissions and saving of 2.52 million cubic meters of landfill volume. The cumulative result observed during 2010-2013 has been presented in Fig. 2. 


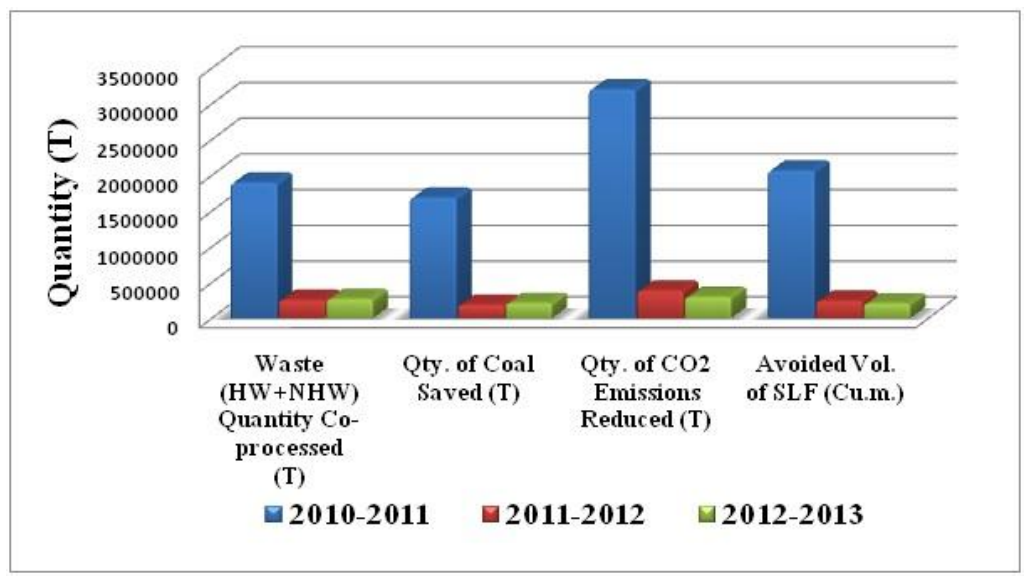

Fig. 2: Quantified reduced environmental impacts

\section{Discussion}

A variety of wastes are generated through various sources, but all the wastes can not be co-processed in cement kilns. Therefore, requirement to identify the suitable wastes for co-processing having no adverse environmental impacts due to emission of all possible pollutants, with quantification of reduced environmental impacts by using waste co-processing was needed. Literature, so far, do not quantify the amount of GHGs emitted; Coal \& SLF volume saved due to co-processing of identified suitable wastes, having no adverse environmental impacts at the same time. Some studies involved the risks and benefits of co-processing, similar to Huang et al [15], but the potential benefits have not been quantified. Our study focused on presenting the clear picture of actual quantification of benefits of co-processing the wastes in cement kilns, taking into consideration the environmental impacts of all the possible pollutants through flue gas emissions, without affecting the cement quality and thus helped in developing a database of quantified benefits of waste coprocessing. By detailed analysis of the data collected during regular co-processing of wastes in cement kilns, it was observed that:

- Dust: There was no impact on dust emissions while using alternate fuels (i.e. wastes) in cement kilns. Particulate matter was not exceeding the emission standards set by SPCBs.

- Sulphur oxides (SO2): Alternate fuels had no influence on total SO2 emissions.

- Nitrogen oxides (NOx): NOx emissions generated from cement industries have three main contributors: Thermal, Fuel and Feed. However, fuel NOx is having less contribution as compared to other sources. From co-processing of alternate fuels, NOx emissions could be lower/higher depending on characteristics of alternate fuel and excess air requirements.

- Total organic carbon (TOC): There seemed to be no correlation between the use of alternate fuels and emissions levels

- Cyanide (CN): Cyanide was not found in Kiln

- Polychlorinated dibenzo-p-dioxins and polychlorinated dibenzofurans (PCDD/ PCDF): Total Dioxin and Furan emissions were well below the emission standards of $0.1 \mathrm{ng} / \mathrm{Nm} 3$, when alternate fuels were used.

- Hydrogen Chloride: $\mathrm{HCl}$ may increase if chlorinated waste is used as alternate fuels. However, $\mathrm{HCl}$ emissions were found to vary irrespective of the fuel.

- Polycyclic Aromatic Hydrocarbons: PAH were observed in some plants using plastics and hazardous waste like Benzofurans. However, PAH remained below detectable limit (BDL) for other alternate fuels.

- Heavy metals: Nearly most of them remained either in the cement clinker matrix or the cement kiln dust as non leachable compounds. However, total emissions were well below the emission standards of 0.5 $\mathrm{mg} / \mathrm{Nm} 3$, when alternate fuels were used.

\section{Conclusion}

Co-processing of waste to replace virgin resources in the energy-intensive industries like cement plants has proved to be a valuable element in sustainable development.

In a developing country like India, there is a huge potential of waste generation, which can be utilized in cement kilns.

The identified suitable wastes have no adverse impacts on environment due to emissions of various pollutants during co-processing of wastes, as the emissions during co-processing were not exceeding the baseline emission i.e. emission during utilization of coal only, during pre co-processing. The clinker quality and cement strength were not affected by identified waste co-processing and the ambient air quality was meeting the 
National Ambient Air Quality Standards, prescribed by Ministry of Environment \& Forests, India. Thus, the identified wastes can be co-processed in cement kilns on regular basis without any further trial runs.

The scientific disposal of wastes through co-processing not only serves as a viable solution to the menace of waste disposal but also saves a great amount of landfill volume \& huge quantity of coal, resulting in reduction of greenhouse gas emissions upto a great extent.

As countries strive for greater self-sufficiency in hazardous waste management, particularly in developing countries that may have little or no waste management infrastructure, properly controlled coprocessing can provide a practical, cost-effective and environmentally preferred option to landfill and incineration Therefore, the co-processing of wastes in cement kilns should be promoted for sustainable development.

None

\section{Acknowledgements}

\section{Competing Interests}

There are no financial or non-financial conflicts of interest.

None

\section{SOURCE OF FUNDING}

\section{Authors' Contributions}

All authors have contributed to research study, visiting plants, collecting data, writing the research report, reviewing and have given the final approval for publishing the manuscript.

\section{References}

[1] HW (MHTM) Rules 2008. Hazardous Waste (Management and Handling \& Transboundary Movement) Rules, Delhi, (2008). Ministry of Environment and Forests (MoEF). http://www.legalpundits.com/Content_folder/Haz07112008.pdf

[2] Shukla B. P., Dave S, Bala S. S., Gupta P. K., Sharma B K, Basu D. D., Kamyotra J. S. Guidelines on Co-processing in Cement/Power/Steel Industry. CPCB (2010).

http://www.cpcb.nic.in/divisionsofheadoffice/hwmd/Latest_51_Latest_51_GUIDELINES-ON_CO-Processingin Cement.pdf

[3] Conference of the Parties to the Basel Convention on the Control of Transboundary Movements of Hazardous Wastes and Their Disposal. Tenth meeting. Cartagena, Colombia, 17-21 October 2011. Draft decision BC-10/[ 8]: Technical guidelines on the environmentally sound co-processing of hazardous wastes in cement kilns.

[4] Mantus, E.K. 1992. All fired up: Burning Hazardous Waste in Cement Kilns. Washington: Environmental Toxicology International

[5] Battelle (Battelle Memorial Institute). 2002. Toward a Sustainable Cement Industry. Commissioned by the World Business Council for Sustainable Development. http://www.wbcsd.org/web/publications/batelle-full.pdf

[6] WBCSD (World Business Council for Sustainable Development). 2005. Guidelines for the Selection and Use of Fuels and Raw Materials in the Cement Manufacturing Process. Cement Sustainability Initiative (CSI). Geneva: WBCSD. http://www.wbcsd.org/includes/getTarget.asp?type=d\&id=MTc4NjA

[7] Karstensen, K.H. 2007. National policy on High Temperature Thermal Waste Treatment and Cement Kiln Alternative Fuel Use: Cement Production Technology. Department Environmental Affairs and Tourism of the Republic of South Africa. http://www.deat.gov.za//PolLeg/GenPolicy/2008Sep25/cement.html

[8] GTZ/Holcim. 2006. Guidelines on Co-Processing Waste Materials in Cement Production. The GTZ- Holcim Public Private Partnership. http://www.coprocem.com/Guidelines

[9] Murray, A. and Price, L. 2008. Use of Alternative Fuels in Cement Manufacture: Analysis of Fuel Characteristics and Feasibility for Use in the Chinese Cement Sector. China Energy Group, Ernest Orlando Lawrence Berkeley National Laboratory, U.S. Department of Energy. http://china.lbl.gov/publications/use-alternative-fuels-cement-manufacture-analysis-fuel-characteristics-and-feasibility-

[10] Co-processing, web matter. http://en.wikipedia.org/wiki/Co-processing

[11] Mutz, D., Andres, C., Hengevoss, D. and Morf, L. 2007. Co-Processing Waste Material in Energy-Intensive Industries (EII): A global study with focus on Europe. University of Applied Sciences Northwestern Switzerland, GEO Partner AG Resource Management.

[12] Karstensen, K. H. 2009. Guidelines for co-processing. Proceedings of "China International Conference on the Utilization of Secondary Materials and Fuel in Building Materials Industry". Institute of Technical Information for Building Materials Industry of China, No.1, Guanzhuang Dongli, Chaoyang District, Beijing, China. Beijing International Exhibition Center. 29 June 2009.

[13] OECD (Organisation for Economic Co-operation and Development). 2000. Strategic Waste Prevention, OECD Reference Manual. ENV/EPOC/PPC(2000)5/FINAL

[14] Karstensen, K. H.; Kinh, N. K.; Thang, L. B.; Viet, P. H.; Tuan, N. D.; Toi, D. T.; Hung, N. H.; Quan, T. M.; Hanh, L. D.; Thang, D. H. Environmentally sound destruction of obsolete pesticides in developing countries using cement kilns. Environ. Sci. Policy. 2006, 9, 577-586

[15] Huang Q.; Yang Y; Wang Q. Potential for serious environmental threats from uncontrolled co-processing of wastes in cement kilns. Environ. Sci. Technol., 2012, 46 (24), pp 13031-13032.

[16] Li Y.; Wang H.; Zhang J.; Wang J (2012). Disposal of obsolete pesticides including DDT in a Chinese cement plant as blueprint for future environmentally sound co-processing of hazardous waste including POPS in the cement industry. Procedia Environmental Sciences 16 ( 2012$) 624-627$.

[17] Garcia I. G., Moura F.J., Bertolino L.C., Brocchi E.D.A. (2013). Industrial experience with waste co-processing and its effects on cement properties. Environmental Progress \& Sustainable Energy. http://onlinelibrary.wiley.com/doi/10.1002/ep.11873/abstract

[18] Bundela, P. Singh; Chakrawarty, Momita; Gautam, S. P. (2010). Co-Processing Trial of Spent Carbon at Wadi Cement Works Karnataka. American Journal of Environmental Sciences;2010, Vol. 6 Issue 4, p371 
[19] Van Oss, H.G. and Padovani, A.C. 2003. Cement manufacture and the environment. Part II: Environmental Challenges and Opportunities. Journal of Industrial Ecology, 7 (1), 93-126.

[20] UNEP (United Nations Environment Programme). 2007. Guidelines on Best Available Techniques and Provisional Guidance on Best Environmental Practices Relevant to Article 5 and Annex C of the Stockholm Convention on Persistent Organic Pollutants: Cement Kilns Firing Hazardous Waste. Expert Group on Best Available Techniques and Best Environmental Practices. Geneva: UNEP.

[21] EIPPCB (European Integrated Pollution Prevention and Control Bureau). 2010. Reference Document on Best Available Techniques in the Cement, Lime and Magnesium Oxide Manufacturing Industries (May 2010). European Commission, Joint Research Centre, Institute for Prospective Technological Studies. Seville. ftp://ftp.jrc.es/pub/eippcb/doc/clm_bref_0510.pdf

[22] Rushworth J. (2002). Ad hoc 7 Working Group on Innovation and Technology Perspectives in Energy Intensive Industries in Europe. http://ec.europa.eu/enterprise/policies/sustainable-business/files/environment/hlg/doc_06/ah_group_7/j_rushworth_en.pdf. 